\title{
КОНФЕРЕНЦИЯ ПО ЭЛЕКТРИЧЕСКИМ ЦЕПЯМ С ВЕНТИЛЯМИ
}

С 2 г по 26 июня 1959 г. в г. Львове прохоцила конференция по электрическим цепям с вентилями, созванная институтом машиноведения и автоматики АН УССР совместно с Московским ордена Ленина энергетигесим институтом и Львовским политехническим институтом.

В конференции приняли участие более 40 научно-исследовагельских институ- тов, высших учебных заведений, констругторских бюро и предприятий Москвы, Ленинграда, Қиева, Львова, Новосибирска, Томска, Ташкента, Риги, Горького н других городов страны.

На конференции заслушано и обсуждено 46 докладов, посвященных инженерным методам расчета и конструирования электрических устройств с вентильными элементами (средств автомағ 
тизацин, электронзмерительных приборов, выпрямителей и преобразователей электрической энергин, электронных вычислительных машин, устройств связи и т. д.), разработке новых вентильных элементов, изучению физических процессов в вентилях и совершенствованию методов анализа электрических цепей $c$ вентилями.

Чл.-корр. АН СССР JI. P. Нейман, к. т. н. С. Р. Глинтерник, к. т. н. А. В. Емельянов и В. Г. Новицкий посвя. тили свой доклад основным вопросам обеспечения надежности работы мощных ионных преобразователей в энергетических системах, которые приобретают особое значение при сооружении электропередач постоянного тока, как звеньев единой энергетической системы СССР

В докладе д. т. н. И. Л. Каганова была изложена теория вентильного действия полупроводниковых диодов и триодов и показано, как она отражается в эквивалентных схемах. Особое внимание в докладе уделено работе полупроводниковых триодов на высоких часTotax.

В докладе д. т.н. Г. Е. Пухова изложен предложенный автором и Б. А. Борковским точечно-итерационный метод расчета периодических процессов в электрических цепях, содержаших нелинейные сопротивления, индуктивности, емкости, а также применение метода к случаю, когда нелинейными элементами являются выпрямители.

Большой интерес вызвал доклад Л. Л. Иванова, который изложил результаты своих исследований по разработке аналитической теории разрывных функций и ее применению $\mathrm{k}$ расчету нелинейных электрических цепей.

В докладе д. т. н. Б. М. Шляпошникова проанализированы существенные различия между основными параметрами линейных и нелинейных элементов и указаны ошибки, к которым может привести игнорирование этих различий

Доклад к. т. н. В. П. Сигорского посвяшен применению метода припасовывания $k$ анализу нелинейных электрических цепей. Рассмотрены пути расчета периодических режимов сложных схем, содержащих несколько реактивных элементов и вентилей, и получены уравнения периодов в общем виде. Ряд задач доведен до решения трансцендентных уравнений относительно моментов перехода вентилей из одного состояния в другое, причем результаты представлены в виде графиков, удобных для инженерных расчетов. Обсуждались возможности применения электронных вычнслительных машин при расчете нелинейной цепи методом припасовывания.

В докладе к. т. н. Л. А. Синнцкого о периодических режимах в цепях с выпрямителями и катушками с железом рассмотрены случаи, когда в цепи имеется единственный периодический и притом устойчивый режим.

Ю. $M$. Шумков посвятил свой доклад выбору аппроксимацин характеристики полупроводникового выпрямителя.

В докладе В. М. Бондаренко предложен простой метод определения гармонических составляющих тока нелинейной цепи с выпрямительными элементами.

В докладе к. т. н. С. Р. Глинтерника дан анализ электромагнитных процессов в ионных преобразователях частоты при помоши кусочно-линейного метода. В другом докладе С. Р. Глинтерника изложен приближенный метод расчета электрических цепей с ионными греобра. зователями, основанный на допущении o прямолинейном характере коммутации тока.

Ф. Е. Пашуканис доложил о расчете феррит-диодных схем с учетом динамических процессов в полупроводниковом диоде. В. Г. Бондарчук изложил итерационный метод диодиых цепей, применяемых в электронных вычислительных машинах. В докладе E. Н. Курилова прнведен расчет частотных погрешностей измерительных схем с выпрямителямк. К. т. н. В. А. Кочан осветнл в своем докладе вопросы, связанные с выбором схемы включения выпрямителей в детекторных приборах и устройствах.

Вопросам повышения точности инженерных методов расчета выпрямительных устройств посвятили свой доклад к. т. н. Е. Ф. Замора, к. т. н. Э. М. Мушкарден, к. т. н. Г. А. Шевцов. В докладе А. М. Ляшенко изложены теория и расчет выпрямителей $c$ нагрузкой, шунтированной емкостью. О. К. Щербаков дал инженерный расчет стабнлизированных выпрямителей, предназначенных для электропитания вычислительных ма. шин. Вопросы расчета выпрямительных и стабилизирующих устройств были освещены также в докладах В. А. Виентиесиса, Н. А. Левина, Л. Н. Мелдериса, Л. Я. Мисуловина и В. Ф. Ждан.

Д. т. н. Б. П. Терентьев отметил основные недостатки электронно-импульсных методов управления ионными выпрямителями и нх защиты и указал на возможные решения отдельных узлов схем управления и зашиты.

Д. т. Н. А. М. Бамдас и А. П. Кузь мин поделились опытом разработки исследования многоступенчатых трехфаз. ных выпрямнтельных установок с бестоковой коммутацией.

Различные вопросы выпрямительной техники были рассмотрены также в докладах: к. т. н. В. Н. Аксенова о системе защиты тиратронного выпрямителя, д. т. н. А. Н. Миляха и к. т. н. Б. Е. Кубышина об устройстве для реверсирования выпрямленного тока для гальванических цехов, к. т. н. А. Ф. Крогериса и Я. К. Шинки о новых установках с германиевыми выпрямителямн, разработанными в ИЭЭ АН Латв. ССР, Г. П. Мостковой о регулировании напряжения в схемах с неуправляемыми вентилями при помощи насыщенных реакторов. 
В докладе д. т. н. С. В. Страхова дан анализ переходных электромеханических процессов в системе дизель-синхронный генератор - асинхронный двигатель при наличии выпрямителей в цепях компаундирования и возбуждения синхронного генератора.

Доклад В. 3. Ярины посвящен теоретическому и экспериментальному иссле. доьанию схемы вентильно-контактного каскада для регулирования скорости асинхронного двигателя и сравнению ее со схемой вентільного каскада на ионных приборах.

$B$ докладє к.т.н. Э. А. Якубайтиса нзложены результаты разработки автомагического регулятора возбуждения самовозбуждаюшегося синхронного генератора с использованием полупроводниковых диодов и триодов. В другом докладе к. т. н. Э. А. Якубайтиса и М. П. Вайварса приведен расчет-однофазного мостового полупроводникового выпрямителя в цепя $\mathrm{x}$ управления.

Л. Е. Дударев осветил в своем докладе вопросы, ввязанные с обеспеченнем специальных требований с помощью выпрямителей в цепях управления шахтным взрывобезопасным электрическим привоцом.

В. И. Гольдгефтер и к. т. н. Л. Я. Мизюк доложили о возможности создания параметрических фильтров с использованием нулевых биений, которые позволягт резко уменьшить плотность спектра на выходе, исключая в то же время зеркальный канал. Фильтры с использованием нулевых биений могут быть построены на механических преобразователях, полупроводниковых диодах и трнодах и т. д.

В докладе Х. М. Желиховского рассмотрены вопросы осушествления схем автоматического контроля изоляции $\mathrm{c}$ использованием выпрямителей. К. т. н. Я. С. Авербух сообщил об универсальных измерительных приборах с полупроводниковыми выпрямителямн, разработанных Қиевским заводом «Точэлектропрнбор». О специальных схемах выпря мительных приборов для измерения сопротивпения изоляции сетей переменного тока, находяшихся под напряжением, а также о применении выпрямительных приборов для измерения переменного то. ка и напряжения частотой $0,5-1,5$ си сообцил П. Б. Усатин.

Доклад о применении полупроводни. ковых элементов в устройствах автоматики и телемеханики на железнодорожном транспорте сделал $M$. $M$. Қирнлов.

В докладе Ж. И. Алферова было сообщено, что на кремниевых сплавных диодах с малой плошадью перехода удалось наблюдать явление «пробоя» в пропускном направлении при контактных температурах. На основании этого разработаны методы изготовления крем-

Поступила в редакцию 9 VII 1959 г. ниевых диодов с отрицательным сопротивлением.

В. И. Стафеев и Э. И. Каракушан сообщили о магнитном управлении током диодов. Разработаны магнитодиоды, напряжение и ток которых резко меняются в магнитном поле. Магнитодиоды могут получить применение как в приборах, использующих измерение постоянных и особенно переменных магнитных полей, так и для усиления электрических сигналов.

Д. Н. Наследов, Н. Н. Смирнова и Б. В. Царенков в своем докладе рассмотрели перспективность применения пгоскостных и точечно-контактных днодов на основе арсенида галлия, имеющих ряд преимушеств перед кремниевыми диодами.

В докладе О. А. Коссова показана возможность создания регулируемых выпрямителей на полупроводниковых приборах и исследованы особенности таких выпрямителей.

П. И. Дехтеренко показал удобство применения на инфранизких частотах управляемого релейного синхронного детектора, позволяющего простыми средствами осуществлять изменение как синусоидального напряжения, так и основной составляюшей несинусоидального напряжения на выходе нелинейной системы.

В докладе Ю. И. Дрсбовича рассмотрена работа мощных полупроводниковых триодов в режиме насыщения в переключающих и выпрямительных схемах, когда триод по свонм параметрам приближается к ндеальному ключу.

В докладе Н. С. Яковчука и И. И. Родичева рассмотрены: установка для исследования в имлульсном режиме диодов, работающих в закороченном направлении; импульсный характернограф, предназначенный для визуального наблюдения статических характеристик полупроводниковых диодов при весьма малых рассеиваемых мочцностях; экспотенциометр, служащий для исследования прямой ветви характеристики полупроводниковых выпрямителей.

B решении, принятом конференцией, указывается на важное народно-хозяйственное значение техники преобразования и выпрямления электрнческого тока, особенно в связи с одной из основ ных задач семилетнего плана - автома тизацией производственных процессов.

Конференция выявила недостатки в области координации научно-исследовательских работ и взаимной информации. В ряде важнейших направлений иссле дования развиты в недостаточных масштабах, а их результаты медленно внедряются в практику. Ведущне журналы мало освешают вопросы теории и практики нелинейных электрических цепей. особенно цепей с вентилями.

К. т. н. В. П. Сигорский 